\title{
FLORISTIC METAPHORS IN LATIN AND ENGLISH PHARMACEUTICAL TERMINOLOGY
}

\author{
Victoria Lozenko \\ Ph.D., Assistant Professor, Kharkiv National Medical University, Ukraine \\ e-mail: lozenkoviktoria5@gmail.com,orcid.org/0000-0003-1248-0534
}

\section{Summary}

The article highlights metaphorization of floristic vocabulary in Latin and English pharmaceutical terminology. Nominations of plants are considered to be motivated semantically: the inner form of metaphors proves explicit or implicit one. There are used the cognitive method (works by Y. Stepanov (Stepanov, 2001), V. Telia (Telia, 1988), A. Wierzhbicka (Wierzhbicka, 1969) and method of metaphor (works by N. Arutyunova (Arutyunova, 1990), G. Lakoff and M. Johnson (Lakoff et al., 1980), V. Telia (Telia, 1988) for the research. The article focuses on primary floristic nominations and secondary ones based on associative peculiarities. The comparative method enables to examine the specificity of floristic metaphors in Latin and English. The research has found motivation of metaphoric nomination in English and Latin medical terminology. In addition, there have been found similar and peculiar features in nominations of plants, flowers, bushes, trees in English and Latin of medicine.

The process of methaphorization is inherent for majority of Latin and English pharmaceutical phytonyms. It leads to the conclusion that metaphorization proves considerable process for comprehension of specificity of different national linguistic view of the world.

Keywords: metaphor, phytonyms, floristic lexemes, Latin terms of pharmacy, English terms of pharmacy, similar and peculiar features, metaphorical models, phytonymical components.

DOI: https://doi.org/10.23856/4608

\section{Introduction}

Linguistics has always studied metaphors in different languages. Metaphorical nominations are known to play the key role in medical terminology, especially in Latin and English pharmaceutical terminology.

The aim of the article is to examine floristic metaphors in Latin and English pharmaceutical names of plants, flowers and trees.

The object of the research is the most famous pharmaceutical Latin and English names written out in the prescription.

Topicality is determined by widespread usage of Latin and English metaphors in pharmaceutical names of plants. The most of these metaphors derive from Greek and Latin mythology: mythological characters, events, associations etc. It has become apparent in recent years that translation of metaphors have been still the aim of researchers because the national linguistic view is different for representatives of different cultures.

Scientific novelty implies correlation of the "metaphor" with Latin and English floristic names of plants.

Methods of research. Latin floristic mythometaphorical names of plants are examined by means of the cognitive and method of metaphor. These methods contribute to study the explicit and the implicit forms of English and Latin metaphors. 


\section{Approaches to the concept "metaphor"}

Metaphors have been studied in the works by G. Lakoff and M. Johnson, V. Telia, A. Wierzhbicka. Accoding to G. Lakoff and M. Johnson, metaphor is considered to be a means of comprehension of the thing in terms of another. G. Lakoff and M. Johnson described the main metaphorical models, highlighted metaphorical systematicity, defined peculiarities of metaphor and metonymy, outlined metaphorical coherence. These famous scientists found out that metaphors allow us to express our feelings and abstract concepts.

Semantic structure of metaphor has two components: its meaning and the image of its accessory subject. Researchers Zhdanova E., Abzhamalova N., Svich N. give examples: white of the egg, white of the eye, howl of animals, howls of the wind, wave of a river $\backslash$ sea and wave of tenderness, fever and love fever etc.

Arutyunova outlines types of linguistic metaphor: nominative, cognitive, imaginary, generalizing metaphor (as the result of cognitive metaphor. In the base of metaphor there can be put similarity of various signs $\backslash$ features of an object: colour, form $\backslash$ shape, volume, purpose, position etc.

Cognitive linguistics (G. Lakoff, R. W. Langacker (Langacker, 2000), L. Talmy (Talmy, 2000) considers metaphor not only as a linguistic phenomenon but as a mental, cultural one that enables to highlight the national specificity. Conceptual metaphor is believed to be the main way of modeling reality. In this case conceptual metaphor proves a kind of mental process. Meanwhile, cognitive metaphor defines a lexeme as a mental product formed by certain culture. For example, one of English metaphors is the metaphor "person-island". This metaphor is perceived as a geographical category but as personification of the specific inner world of an Englishman with his aspiration to privacy and isolation.

\section{Latin and English floristic metaphors}

One of the famous plants is Adonis vernalis (Latin) translated into English as pheasant's eye, spring pheasant's eye, yellow pheasant's eye and false hellebore. Adonis is a character from Greek mythology, very handsome hunter (Dvoretskyi, 1998:29). Once Adonis was attacked by a wild boar and died. Another name of this plant, pheasant's eye, emphasizes the resemblance between the flower and the red eye of a pheasant. It is worth focusing on the fact that it is preferable to use latinized form of this name of the plant in academic literature. However, in some academic reference books one can find English name (pheasant's eye) next to latinized form.

The well-known flower by the Latin name Narcissus has English name daffodil. According to Greek mythology, Narcissus is a handsome young man who despises everybody (Dvoretskyi, 1998:503). Narcissus was punished by the goddess Nemesis for his scorn: the young man fell in love with his own reflection. The English name daffodil is associated with the colour of the flower. In addition, it is worth outlining that a daffodil is a national emblem of the Welsh. In the Welsh culture a daffodil can be related to the people fom Wales, their culture, traditions, customs and mentality.

The Latin name of the plant Atropa Belladonna (Latin pharmaceutical name Belladonna) is known by the English name belladonna or deadly nightshade. The genus name Atropa derives from the name of one of the three goddesses of fate in Greek mythology: she cut the thread of life, after that a human died. So far the Latin $\backslash$ the Greek name of the plant is associated with death, which is explained with the toxic of belladonna: the foliage and berries are very toxic. 
They can affect the organism and lead to death. As Latin name, as English name deadly nightshade emphasizes the toxic of the plant.

The name bella donna is translated from Italian into English as "beautiful woman". In the Middle Ages and the Renaissance women used the herb of the plant for eye-drops. Eyedrops with belladonna dilated the pupils of the eyes: it was considered to be very attractive and seductive.

The Latin name of the flower Hyacinthus is translated into English as common hyacinth, garden hyacinth or Dutch hyacinth. This is Greek borrowing. In Greek mythology Hyacinthus or Hyacinthos was a young man protected by the god Appollo. Hyacinthos was killed by an Appollo's discus accidentally during a game. According to the legend, a beautiful violet flower appeared from Hyacinthos's blood. In ancient Greece the flower was the symbol of sadness, sorrow, grief and mourning. Meanwhile, in ancient Rome the flower was believed to be the symbol of joy, gladness, mirth, sunshine and youth. It was related to celebrations in honor of the goddess Flora, the goddess of spring. Young girls and women weaved into a hair flowers of hyacinth for attracting men' attention. Nowadays, in addition to mythological origin of the name Hyacinthus, the name hyacinthus $\mid$ hyacinth highlights only the place of flourishing: such flowers flourish only in the season of rains (hyacinth means "the flower of rain").

The Latin pharmaceutical name Delphinium is known by the English name one larkspur. The most of species are toxic ones. There are several explanations to the origin of the name. According to etymology, the name "delphinium" comes from the Latin "dolphin" due to the resemblance of the shape and the body of the dolphin. If one consults an ancient Greek dictionary, he $\backslash$ she finds out that this word means "larkspur". The plant got such name because of similarity of the sepal to cavalry spur. The literal translation from German is knight's spur, from English (there are several names) "spur of a lark", "heel of a lark", "funny spurs", "claw of a lark", from French "foot of a lark". It is worth focusing on the fact that there is another version of the origin of this plant: the name derives from the name of an ancient Greek city Delphie surrounded by these flowers. In Delphie a famous temple to Appollo was situated and a delphian oracle. To sum up, it leads to the conclusion that the base of Latin nomination is the shape of the flower. The Greek nomination is associated with geographic position.

One more famous flower is Protea (Latin name), also called fynbos or sugarbushes. The flower was named after the sea-god Proteus, a well-known character from ancient Greek mythology. This god had ability to change his appearance. The Proteaceae family got its name after this sea-god due to inconceivable variety of shapes and sizes. The Protea flower produces a large amount of nectar, hence the English common name "sugarbush". The Protea flowers represent huge heads with cluster of flowers in the center surrounded with large bright bracts. Immense flowers produce from 6 up to 10 flower heads for one season.

It is worth outlining that the Protea flower decorates the coat of arms of republic of South Africa. The Protea flower is known to be the national flower of South Africa.

The flower with the Latin name Convallaria majalis is known by the English one as lilyof-the-valley, may bells, our Lady's tears or Mary's tears. All the plant of the flower is toxic. However this flower is used in pharmacy for preparation of medicines. As a raw material, herb, the foliage and flowers of the plant are used as components of cholagogic remedies at cholecystitis and cardiotonic medicines. Lilies-of-the-valley are widely availed as the base of perfumes. There are several legends relating to the origin of the name "lily-of-the-valley" and a flower by itself. The lily-of-the valley grows in the greenwood, pine forest, glades, the edge of the forest on the valleys or a kind of the lawn reminding the valley. 
As for the origin of the flower, in Roman mythology the goddess of the hunt Diana running from fauns covered in beads of sweat which dropped on the ground and turned into fabulous flowers. The famous fairy-tale about Snow White and seven dwarfs by the brothers Grimm tells us about Snow's White necklace. Accidentally Snow White tears and scatters the pearls of the necklace which changes into fragrant flowers. In the fragrant flowers sunbeams appear and dwarfs use them as flashlights. In the epoch of the Middle Ages people were trying to find hidden treasures by means of the lily-of-the-valleys flowers.

The lily-of-the-valley is also called as our Lady's or Mary's tears because her tears shed on the Holy Cross turned into the lily-of-the-valley flowers.

The lily-of-the-valley represents the symbol of purity, happiness, luck, chastity and humility. In France, on the First of May, people celebrate the lily-of-the valley day. This flower is the official flower emblem of the Swedish province Gästrikland. To sum up, one can draw the conclusion that dominant motivated sign is the peculiarities of the plant (fragrant scent) and the place of growing (valleys).

The well-known plant with the Lain name Leonurus cardiaca is motherwort in English. There are several translations for Leonurus from Latin into English: motherwort, throw-wort, lion's ear, lion's tail. The most common name is motherwort. In English this plant got such name due to healing characteristics for treating uterine diseases and female disorders.

In Latin the lexeme Leonurus is known to derive from leo (lion) and oura (tail) due to inflorescence. The adjective "cardiaca" highlights that the plant is good for treating heart diseases. So far the dominant motivated base for metaphor in English is designation. In Latin the dominant base is shape. Designation or usage for treatment figures only as the accessory sign $\backslash$ feature in Latin.

\section{Conclusions}

All the above mentioned leads to the conclusion that a large number of nominations highlights shape $\backslash$ form, size, appearance, resemblance with the shape of an animal as in English (lily-of-the-valley, larkspur, pheasant's eye) as in Latin (Convallaria, Delphinium, Leonurus, Protea); landscape (Convallaria \lily-of-the-valley, Delphinium \delphinium). Sometimes the metaphorical nomination serves as the means of symbolizing human's emotions: hyacinth is the symbol of sadness, sorrow in ancient Greece and, on the contrary, this is the symbol of joy, happiness and sunshine in ancient Rome.

It is worth focusing that a plant or a flower can figure as the national emblem or the symbol of the country or the province regardless of the language of nomination of the plant: the lily-of-the-valley symbolizes the Swedish province Gästrikland; the Protea flower is associated with South Africa; the daffodil flower is the symbol of the Welsh culture.

In English there are floristic nominations which keep their vivid internal form: pheasant's eye, larkspur, lily-of-the-valley, sugarbush etc. The metaphorical meaning develops imaginary opportunities of internal form of floristic nominations.

The comparison of floristic metaphor in English and Latin admits to draw the conclusion that in process of modeling metaphoric meanings the most topical implicit meaning proves transfer of the nomination "flower - part of an animal's body". The least widespread meaning in English is the implicit meaning "flower - colour" (daffodil is also light yellow colour); in Latin the least topical meaning proves "flower - ability of changing shape $\backslash$ appearance" (the Protea flower). 


\section{References}

Arutyunova, N. D. (1990). Teoria metafory [The theory of metaphor]. Moscow: Progress. [in Russian].

Dvoretskyi I. H. (1998). Latinsko-russkii slovar [The Latin and Russian dictionary]. Moscow: Russkii yazyk. [in Russian].

Kittey, E. (1989). Metaphor. Its cognitive force and structure. Oxford: Clarendon Press.

Kövecses, Z. (2000). Metaphor. A practical introduction. Oxford: Oxford University Press.

Langacker, R. W. (2000). A course in cognitive grammar. San Diego: University of California. Langacker, R. W. (1987). Foundations of cognitive grammar. Stanford, CA: Stanford University Press.

Lakoff, G., Johnson, M. (1980). Metaphors we live by. Chicago: University Press of Chicago. Lakoff, G., Turner M. (1989). More than cool reason: A field guide to poetic metaphor. Chicago: University of Chicago Press.

Stepanov, Y. S. (2001). Konstanty. Slovar russkoi kultury [Costants. The dictionary of Russian culture]. Moscow: Akademicheskyi proekt. [in Russian].

Talmy, L. (2000). Toward a cognitive semantics. Cambridge, MA: MIT Press.

Telia, V. N. (1988). Rol chelovecheskogo faktora v yazyke: Yazyk i kartina mira [The role of human factor in the language: Language and the view of the world]. Moscow: Nauka. [in Russian].

Wierzbicka, A. (1969). Semantics: Primes and Primitives. New-York: Oxford University Press. Zhdanova, E. A., Abzhamalova N. D., Svich N. A. Metafora i protsess metaforizatsii znacheniya slov [Metaphor and process of metaphorization of meanings of words]. URL: https://scientific-conference.com/images/PDF/2017/35/metaphor.pdf 